\title{
The study of comparisons of Muraqabah (self Control) Students Student boarding schools of Jagad 'Alimussirry with the students in the UNESA
}

\author{
M N B W Sukma ${ }^{1}$, H Aliyah ${ }^{2}$ \\ ${ }^{1}$ Islamic Building School of Jagad 'Alimussirry Surabaya, Indonesia \\ ${ }^{2}$ Science Department, Universitas Negeri Surabaya \\ Email: nikibagus25@gmail.com
}

\begin{abstract}
The purpose of this research was to analyze the difference in self control students student boarding schools of Jagad 'alimussirry with the students in the UNESA. This research is both a quantitative approach to the field (field research). Determination of the sample in this research was conducted with a purposive sampling technique. Based on the engineering samples taken as many as 105 subject, 18 students from boarding schools of Jagad ' alimussirry and 87 of the students from several departments. Data collection was done through the dissemination of the scale. The data analysis used the t-test is a test that is independent sample test with the help of SPSS (Statistical Product and Service Solution) 23.0 version for windows. The results can be seen from the results of a test of the hypothesis gained 0.106 significance so $(p>0.05)$. This result shows that shows that Ho is accepted which means no difference a change or an increase in the average value of self control was significant between a group of students and students from various PPJA majoring in UNESA.
\end{abstract}

Keywords: Self Control, Muraqabah, Santri, Students

\section{INTRODUCTION}

Self control is concerned with how individuals control their emotions and impulses in himself. Self control can be successful when the reaction of the public toward the control of emotion is positive. However, a positive reaction alone is not enough because to note other criteria, i.e. effects that emerge after controlling emotions against the physical and psychological conditions. Controlling emotions should not endanger the physical and psychological state of the individual. That is, by controlling individual physical and psychological emotions must be improved. Self control as a way to control your emotions in him. Self control is one of the potential that can be developed and used for individual processes in life, including a condition that occurs in the face of his surroundings. By having a good self control then the mind, feelings, mind and heart spared from destruction or immorality. If the controller is missing then it will have an impact on the weakness of the soul as well as the urge to do good in his personality. Because this is the case then a strong urge to do immoral will arise as deceptive, false, treason, corruption, and the absence of others. If the deed is immoral is often done personal then that person will fall into the Valley of disgrace, moral decline and moral excellence. But noble morals which will be the size of one's personal low high.

Students have good solid activities formal activities in the lesson or a non formal activities within the Organization as well as 
their social life. With the education received by students who expected to be able to run the science to be applied in everyday life especially in science of religion. Religious knowledge is human intelligence for hints to achieve happiness in this world and the hereafter. Religious studies as well as one of the controls in the Act, but the fact that they receive religious education could not be so controlling moral for them. Often times there are still students/i freeloader, hand in hand in the area of the campus, especially going out in place of student so that trigger anxiety. Of the problems that appear on top of making problems for the students in doing self control against moral rated low. The experience endured by students boarding schools of Jagad 'Alimussiry (PPJA) is a positive thing, especially in keeping myself through spiritual activities. Students are also the students provided with supplemental science curriculum in religious boarding schools. Expected with the addition of religious education as well as a good conditioning in religion then it will increase the self control of every student. Often emphasised in order that activities carried out in the boarding schools made the main Foundation can familiarize the brain in positive acts mainly in the activities of everyday life to carry out mundane duties, more related to with the afterlife.

Researchers interested in digging self control students as well as students boarding schools of Jagad 'Alimussirry study of islam Sufism approach that should have the difference if seen by way of processing hemosfir, religious education and activities her everyday, namely with the title "study comparisons of Muraqabah (self control) Students Student boarding schools of Jagad 'Alimussirry with the students in the UNESA".

\section{METHOD}

This type of research is research use the field (Field Research) using the quantitative approaches and methods of comparative techniques with question form. This method is used to collect information regarding the existence of self control students "student Jagad 'Alimussirry that will be compared to public university students (not students). This research aims to get the data from a particular place that is natural to do the treatment in the form of data collection such as questionnaires/question form. Researchers will approach with quantitative research methods that emphasize its analysis on numerical data (numbers) are processed using statistical methods. Comparative research is directed to find out if between two or more than two groups there is a difference in the aspect or the variables examined.

\section{RESULT AND DISCUSSION}

Table i. Classification Analysis Results Data Description

\begin{tabular}{|c|c|c|}
\hline \multirow{2}{*}{ Category } & \multicolumn{2}{|c|}{ Comparison Group } \\
\cline { 2 - 3 } & PPJA (18) & Students (87) \\
\hline Very Low & & $1(1,15 \%)$ \\
\hline Low & & $30(34,48 \%)$ \\
\hline Enough & $3(16,66 \%)$ & $46(52,87 \%)$ \\
\hline High & $12(66,66 \%)$ & $9(10,35 \%)$ \\
\hline Very High & $3(16,66 \%)$ & \\
\hline
\end{tabular}

Processed data can be categorized into 3 namely 3 students (with the interval score value ranging between 137.8-180.2) in conditions of self control, 12 students (with the interval score value ranging between 180.2-222.6) in conditions of self control high, 3 students (with the interval score value ranging between 222.6-265) in conditions of very high self control. Based on the results of categorization that interval then it can be drawn the conclusion that Students boarding schools of Jagad 'Alimussirry has the self control with an average score of 200.11 (high).

Processed data can be categorized into 4 i.e. 1 students (with the interval score value ranging from $95.4-137.8$ ) in conditions of 
low self control, 30 students (with the interval score value ranging between 137.8-180.2) in conditions of self control enough, 46 students (with the interval score value ranging between 180.2-222.6) in conditions of high self control, 9 students (with the interval score value ranging between 222.6-265) in conditions of very high self control. Based on the results of categorization that interval then it can be drawn the conclusion that students from Various Majors have self control with an average value of 190.97 (high).

T-test was conducted to further distinguishing self control students with student PPJA UNESA. With the $t$ test results of significance with 0.106 1.637-so ( $p>0.05$ ). This shows that Ho is accepted which means no difference a change or an increase in the average value of self control was significant between a group of students and students from various PPJA majoring in UNESA. From the two groups have different habits in their brains processed but these factors cannot give effect so that from both groups have self control do not differ significantly. There are other factors that need to be in the review, in which the background of the students is the alumni students boarding schools or not.

With regard to the subjects of this research students and students PPJA, there are some students who have self control (muraqabah) is very high. The corresponding arrangement with muraqabah muraqabah above is just enter into arrangement of muraqabah alshab al yamin. The above described that part of muraqabah alshab al-yamin were the ones who ' from the right wara, a people who have kenyakinan that God sees zahirah and batiniah in his heart. From the explanation above about muraqabah, seen that muraqabah is a form of the Affairs of the heart of the human person with being watched by God Almighty. in all gerak-geriknya, silence so it appears fear to do something that is not tolerated by God Almighty.

A student whose hearts feel watched by God who always run the commandments and prohibitions of Allah menjahui will produce a good self control. The existence of self control on every person of good will also hal-ihwal as well as charitable deeds so that the thought or feeling, sense, and his heart was spared from destruction to immorality.

\section{CONCLUSION}

The level of self control students student boarding schools of Jagad 'Alimussirry with an average score of 200.11 was high. The level of self control students from various majors in the UNESA with average value of 190.97 is high. The results can be seen from the results of a test of the hypothesis gained 0.106 significance so $(p>0.05)$ indicating that Ho is accepted which means no difference a change or an increase in the average value of self control was significant between group Rasta PPJA and students from various majors in the UNESA.

\section{ACKNOWLEDGMENT}

Research done better compare between student alumni cottage with students who have never studied in the hut.

For further research, other researchers should be more in depth, broad range of age, as well as the difference in level of education of the subject that made reference to measure self control to strengthen the results of this research so that it is able to give birth to a the new theory.

\section{REFERENCES}

[1] Al-Ghazali, "Ihya' Ulumuddin," Dar Ihya'il Kutub al-Arabiyah, Juz 4, Bandung: Mizan, 1996.

[2] Amstrong Amatullah, "Khazanah Istilah Sufi: Kunci Memasuki Dunia Tasawuf, terj. M.S. Nasrullah dan Ahmad Baihaquni," Bandung: Mizan, 1996.

[3] Arikunto Suharsimi, "Prosedur Penelitian Suatu Pendekatan Praktik," Jakarta: PT. Melton Putra, 1991.

[4] Azwar Saifundin, "Metode Penelitian," Yogyakarta: Pustaka Pelajar, 2001. 
[5] Badriyah Lailatul, "Pengaruh Empati dan SelfControl Terhadap Agresifitas Remaja SMA Negeri Tangerang Selatan," Skripsi: Program SI UIN Sarif Hidayatullah Jakarta, 2013.

[6] Deporter Bobbi dan Mike Hernacki, “Quantum Learning: Membiasakan Belajar Nyaman Dan Menyenangkan," Bandung: Mizan Media Utama, 2002.

[7] Ghufron M. Nur \& Rini Risnawati, "Teoriteori Psikologi,” Jogjakarta: Ar-Ruzz Media, 2010.

[8] Gunarsa D., "Dari Anak Sampai Usia Lanjut : Bunga Rampai Psikologi Perkembangan," Jakarta : PT BPK Gunung Mulia, 2004.

[9] Goleman, Daniel, "Kecerdasan Emosi Untuk Mencapai Puncak Prestasi," Jakarta:PT. Gramedia Pustaka Utama, 1999.

[10] Hadi Sutisno, "Statistk jilid 2," Yogyakarta: Yayasan Penerbitan Fakultas Psikologi UGM, 1983.

[11] Hartono Djoko, "Amaliyah Thariqat Jagad 'Alimussirry "Wasilah Meraih Maqom Ma'rifatullah"," (Surabaya: Pondok Pesantren Jagad 'Alimussirry (Anggota IKAPI), 2018.

[12] Hendrawan Sanerya, "Spiritual Management: From Personal Enlightenment Towards God Corporate Governance," Bandung: Mizan, 2009.

[13] John Best W., "Research in Education," America: Prentice Hall, 1981.

[14] Johar Danah dan Ian Marshall, "SQ: Memanfaatkan Kecerdasan Spiritual Dalam Berfikir Integralistik Dan Holistik Untuk Memaknai kehidupan," Bandung: MIZAN, 2000.

[15] Kartono Kartini, "Kamus Lengkap Psikologi," Jakarta: Raja Grafindo Persada, 1999.

[16] Liebert R.M, "Development Psychology," New Delhi : Prentice Hall of India, 1979.

[17] Mardalis, "Metode Penelitian Suatu Pendekatan Proposal," Jakarta: Bumi Aksara, 1999.

[18] Meichati, Siti, "Kesehatan mental," Yogyakarta: Yayasan Penerbitan Fakultas Psikologi UGM, 1983.

[19] Nur'ainy, 'Pengembangan Self Control Siswa di SMK PGRI 2 Ponorogo Melalui Penanaman Nilai-nilai Agama," Skripsi: Program S1 STAIN Ponorogo, 2008.
[20] Nurfaujiyanti, "Hubungan Pengendalian Diri (Self- Control) dengan Agresifitas Anak Jalanan," Skripsi: Program S1 UIN Sarif Hidayatullah Jakarta, 2010.

[21] Pasiak Taufik, "Tuhan Dalam Otak Manusia: Mewujudkan Kesehatan Spritual Berdasarkan Neurosains," Bandung: PT Mizan Pustaka, 2012.

[22] Prasetyo Yudi Eko, "Upaya Guru PAI Meningkatkan Self-Control Bagi Remaja (Studi Kasus di SMA Plus YPHB Bogor)," Skripsi: Program S1 Universitas Negeri Jakarta, 2013.

[23] Rahim, “Abu Muhammad. At-Tasawuf al-ladzi Nuriduhu." Kairo: Maktabah Umul- Quran. 2009.

[24] Sudijono Anas, "Pengantar Statistik Pendidikan," Jakarta: PT Raja Grafindo Persada, 2006.

[25] Sugiyono, "Metode Penelitian Pendidikan Pendekatan Kuantitatif, Kualitatif, dan R \& D," Bandung: Alfabeta, 2009.

[26] Sugiharto, “Teknik Sampling," Jakarta: Gramedia Pustaka Utama, 2001.

[27] Sukmadinata, Nana Syaodih, "Metode Penelitian Pendidikan," Bandung: PT Remaja Rosdakarya, 2005.

[28] Sulastri, "Hubungan Muraqabah Dengan Perilaku Agresif Siswa MA NU Miftahul Falah Kudus," Skripsi: Program S1 Institut Agama Islam Negeri Walisongo Semarang, 2013.

[29] Surakhamad Winarno, "Pengantar Penelitian Ilmiah 9 Dasar Metode Teknik," Bandung: Tarsito, 1990.

[30] Suryabrata Sumardi, "Psikologi Pendidikan," Yogyakarta: Raja Grafindo Persada, 1998.

[31] Takhrudin, L.T," Pribadi Pribadi Yang Berpengaruh," Jogjakarta: PT. Alma'arif, 1991.

[32] Tohir Moenir Nahwi, "Menjelajahi Eksistensi Tasawuf Meniti Jalan Menuju Tuhan,” Jakarta: PT. as-Salam Sejahtera, 2012.

[33] Windrawan Hengger Mahardenta, "Hubungan Antara Kontrol Diri Dan Kesepian Dengan Kecanduan Game Online Pada Remaja," Skripsi: Program S1 Universitas Negeri Surabaya, 2014.

[34] [http//Dua Mahasiwa Universitas Islam Negeri (UIN) Walisongo Terlibat Pencurian Laptop 
Milik Teman Satu Kos - Gemamedia News.html (24-02-2019)]

[35] Sutman Resca Hajwan, "Pengaruh SelfControl dan Perilaku Agresi Terhadap Motivasi Belajar Siswa di SMK Muhammadiyah II Kuningan," [Tesis: Pascasarjana Institut Agama Islam Negeri Syekh

NurjatiCirebon2010:digilib_PDF_diundo_24/2 /2019 pukul:9:32 AM] 